\title{
Technical Efficiency and Technology Gap in Indonesian Rice Farming
}

\author{
T. Haryanto ${ }^{1}$, B.A. Talib², N. H. M. Salleh ${ }^{2}$
}

${ }^{1}$ Department of Economics, Airlangga University, Indonesia

${ }^{2}$ School of Economics, The National University of Malaysia

\begin{abstract}
This study aims to estimate the technical efficiency and technology gap in Indonesian rice farming, and analyze its determinants. An analysis of DEA Metafrontier and Tobit regression was applied respectively for the first and second objective. The data is based on farm level data of fifteen rice-producing provinces in Indonesia. The result showed that the technical efficiency based on metafrontier estimation is slightly lower than the technical efficiency based on regional frontier estimation, indicating the existence of technology gap which is quite small. Net income, education, and irrigated rice field found related to the technical efficiency and technology gap. Meanwhile, the effect of other factors on the technical efficiency and technology gap is ambiguous. Hence, this study suggests that these three factors should be considered in the policy to increase technical efficiency and to reduce the technology gap in Indonesian rice farming.
\end{abstract}

\section{Keywords}

Rice farming, technical efficiency, technology gap, DEA metafrontier, Tobit regression.

Haryanto, T., Talib, B. A. and Salleh, N. H. M. (2016) "Technical Efficiency and Technology Gap in Indonesian Rice Farming", A GRIS on-line Papers in Economics and Informatics, Vol. 8, No. 3, pp. 29 - 38. ISSN 1804-1930, DOI 10.7160/aol.2016.080303.

\section{Introduction}

Technical efficiency of rice farming in Indonesia has been investigated by many researchers based on frontier production function estimation. As examples, Widodo (1986) showed that the average technical efficiency of rice farming in West Java is 0.73-0.76, while in Yogyakarta is 0.85-0.86. Squires and Tabor (1991) find that the average technical efficiency of rice farming in Java and off Java is 0.697 and 0.704 respectively. According to Llewelyn \& Williams (1996), the average technical of rice farming in East Java is 0.87. Fabiosa et al. (2004) showed that the average technical efficiency in West Java is 0.66 , while in East Java and Central Java are 0.72 and 0.76 respectively. Study conducted by Brazdik (2006) in West Java showed that the average technical efficiency of rice farming in this region is around 0.60-0.77. A Study by Kusnadi (2011) used a sample of 802 farmers based on PATANAS survey data showed that the average technical efficiency of rice farming in Indonesia is around 0.92. Makki et al. (2012) showed that the average technical efficiency of rice farming in the province of South Kalimantan is 0.78 . Furthermore, Suharyanto et al. (2013) showed that the average technical efficiency of rice farming in the province of Bali is 0.88 .

However, these studies did not take into account the technological gap between the farmers. Thereby, the technical efficiencies are not comparable between the farmers who operate under a given production technology and the farmers which are operating under different production technology. Conceptually, a comparable technical efficiency can be estimated by using metafrontier production function [see Battese and Rao (2002); Battese et al. (2004); O'Donnell et al. (2008); Chen and Song (2008) for a detailed discussion].

A meta production function introduced by Hayami (1969, 1970), Hayami and Ruttan $(1969,1970,1972)$ to explain agricultural productivity differences on a global level. Meta production function or potential production function is described as an envelope for less elastic isoquant of agricultural producer groups in different countries with different technologies (Hayami and Ruttan, 1969), or the envelope for individual production curve (Hayami and Ruttan, 1972). The function can be obtained by estimating general production functions or cross country (Hayami and Ruttan, 1970). 
The concept of meta production is interesting because it incorporate data from different countries to estimate general production function, thus increasing both the range of independent variables or even the total number of observations, and therebyreduce the possibility ofmulticollinearity, improve the reliability of the production estimation. In addition, the meta production function can be estimated using intercountry data, although the individual production functions of the countries can not be estimated using individual country data because the number of observations may not be enough.

Hayami and Ruttan estimate meta production functions using ordinary least squires (OLS) method. Many studies followed the concept and methodology of meta production function estimation [see for example Kawagoe and Hayami (1983); Kawagoe et al. (1985); Lau and Yotopoulus (1971, 1989); Marra and Schurle (1994); Fulginiti and Perrin (1998); Alston et al. (2000)]. Based on the concept of meta production, many studies estimate metafrontier production function to explain the technology gap between producer groups using parametric approach whether deterministic (DFA-MF) or stochastic (SFA-MF), and nonparametric approach Data envelopment analysis (DEA-MF). Kudaligama and Yanagida (2000) estimate DFA-MF and SFA-MF based on the data used by Hayami and Ruttan (1985) by modifying certain variables. The estimation of DFA-MF is conducted by using Minimum Absolute Deviation (MAD) techniques through linear programming (LP) as in Aigner and Chu (1968). Meanwhile, SFA-MF is estimated based on the data of all producers groups, all countries in the same time using a maximum likelihood method. This procedure estimation of SFA-MF is also used by Gunaratne and Leung (2000) to estimate the SFA-MF for black tiger shrimp production systems in Asia.

Rao et al. (2003) estimate DEA-MF and SFA-MF based on FAOSTAT data which consists of 97 major agricultural producing countries in the world. According to Rao et al. (2003), metafrontier function is an envelop to deterministic component of stochastic estimation for different regions. A similar definition can be seen as examples in Battese et al. (2004), Chen \& Song (2008), O'Donnell et al. (2008), and Moreira and BravoUreta (2010). The estimation of SFA-MF use linear programming and quadratic programming techniques. Battese et al. (2004) also apply this estimation procedure for textile industries in Indonesia. Chen and Song (2008) use the same procedur to explain efficiency and technology gap of agriculture in China.

O'Donnell et al. (2008) estimate DEA-MF and SFA-MF based on the same data used by Rao et al. (2003). The estimation of SFA-MF use linear programming technique. The same technique also used by Moreira and Bravo-Ureta (2010) in the study on technical efficiency and meta technology of dairy farms in Argentina, Chile and Uruguay. Some other studies applying DEA-MF to investigate the efficiency and technology differences in agriculture for example Nkamleu et al. (2006), Mulwa et al. (2009), Latruffe et al. (2012), Tung (2014), Nguyen and Fisher (2014). In addition, recent studies using SFA-MF in agriculture as example Uddin et al. (2014), Kramol et al. (2015), Cechura et al. (2015).

Empirically, SFA-MF and DEA-MF are the most widely use to investigate technical efficiency and technology gap in related studies. However, a study conducted by O'Donnell et al. (2008) which is applying both the approaches by using the same sets of data showed that technical efficiency and technology gap based on the estimation of DFA-MF and DEA-MF is greater than technical efficiency and technology gap based on SFA-MF estimation. In addition, the regional technical efficiency is greater than meta technical efficiency. This study employs DEA-MF. Because of DEA use linear programming technique, so that frontier estimated based on all observation data (pooled data) using DEA is already the metafrontier. The next section of this papers sequentially will discuss materials and methods, results and discussion, and conclusion.

\section{Materials and methods}

This study covered of fifteen rice-producing provinces in Indonesia. All the fifteenth of provinces will be grouped into five riceproducing regions, namely Sumatera, Java, Bali and Nusa Tenggara, Kalimantan, and Sulawesi. Total number of observation is 5537 rice farmers. Data used in this study is taken from a survey on the cost structure of rice farming conducted by the Central Bureau of Statistics of the Republic of Indonesia (BPS) in 2008.

An output-oriented DEA model assuming variable returns to scale (VRS) is used to estimate production frontier. The model was adopted from O'Donnell (2008): 
$\max \phi_{i}$

$\phi_{\mathrm{i}}, \lambda_{\mathrm{i}}$

$$
\begin{array}{ll}
\text { st } & \phi_{\mathrm{i}} \mathrm{y}_{\mathrm{i}}-\mathrm{Y} \lambda_{\mathrm{i}} \leq 0 \\
& \mathrm{X} \lambda_{\mathrm{i}}-\mathrm{x}_{\mathrm{i}} \leq 0 \\
& \mathrm{j}^{\prime} \lambda=1 \\
& \lambda_{\mathrm{i}} \geq 0
\end{array}
$$

where $y_{i}=$ the quantity of output in the form of dry grain harvest (in kilograms) of the i-th farmers; $\mathrm{x}_{\mathrm{i}}=\mathrm{N}$ x 1 vector of input quantities for the $\mathrm{i}$-th farmers. These inputs consist of harvested area (in sequare meters), seeds (in kilograms), fertilizer (in kilograms), and labor (in person days); $\mathrm{Y}=\mathrm{L}_{\mathrm{k}} \times 1$ vector of output quantity for all $\mathrm{L}_{\mathrm{k}}$ farmers; $\mathrm{X}=\mathrm{N} \times \mathrm{L}_{\mathrm{k}}$ vector of input quantities for all $L_{k}$ farmers; $j=$ an $L_{k} \times 1$ vector of ones; $\lambda_{\mathrm{i}}=$ an $\mathrm{L}_{\mathrm{k}} \mathrm{x} 1$ vector of weights; $\phi_{\mathrm{i}}=$ a scalar. Solving the linear programming of equation (1) for each region separately will obtain the technical efficiency score for each farmers relative to regional frontier. The value of $\phi-1$ shows the proportional increase in output that can be achieved by the i-th farmers with inputs held constant. The technical efficiency defined as $1 / \phi$ with value between 0 and 1.

A convex metafrontier can be estimated by apply DEA model such as in equation (1) based on pooled data observation of inputs and output for all $\mathrm{L}=\sum_{\mathrm{k}} \mathrm{L}_{\mathrm{k}}$ farmers in all regions (O'Donnell et al., 2008). The optimum solution of DEA metafrontier generates technical efficiency score for farmers in each region relative to metafrontier. The $\phi_{i}$ based on DEA metafrontier could not greater than the $\phi_{i}$ based on DEA regional frontier because of the regional frontier constraints will be part of the metafrontier constraints. Thus, the technical efficiency score based on DEA metafrontier surely could not greater than the technical efficiency based on DEA regional frontier. The estimation of regional frontier and metafrontier is conducted by using DEAP 2.1 version.

Technology gap is measured by metatechnology ratio (MTR). The ratio is defined as technical efficiency based on DEA metafrontier devided by technical efficiency based on regional frontier (O'Donnell et al., 2008; Battese et al., 2004). The value of MTR is between 0 and 1 . MTR closer to 1 indicates that the maximum output achieved by farmers is closer to metafrontier output, meaning that technology gap between regional technology adopted and metatechnology is very small.

Tobit regression models was used to determine effects of the number specific factors on the technical efficiency and technology gap separately. The model is adopted from Chavas and Aliber (1993), Chavas et al. (2005), and Chen and Song (2008) by a modification in variables used. General specification Tobit model is written as:

$$
\begin{aligned}
Y_{i} & =X_{i} \beta+e_{i} & & \text { if } X_{i} \beta+e_{i}<1, \\
& =1 & & \text { otherwise }
\end{aligned}
$$

Model specifications in detail as follows:

$$
\begin{aligned}
Y i & =\beta_{0}+\beta_{1} I N C O M E_{1 i}+\beta_{2} A G E_{2 i}+\beta_{3} E D U_{3 i} \\
& +\beta_{4} S I Z E_{4 i}+\beta_{5} S E E D_{i}+\beta_{6} F I E L D_{6 i}+\beta_{7} P E S T_{7 i} \\
& +\beta_{8} G O V_{8 i}+\beta 9 C R E D I T 9 i+\beta_{10} S U M \\
& +\beta_{11} J A V A+\beta_{12} K A L+\beta_{13} S U L+e_{i}
\end{aligned}
$$

where $Y_{i}$ is the technical efficiency and MTR respectively obtained from the DEA estimation; $\beta$ is unknown parameter to be estimated; $e_{i}$ is an error term, assumed $e_{i} \sim$ iid. $\mathrm{N}\left(0, \sigma^{2}\right) ;$ INCOME $=$ net income from rice farming (in $\log$ ); $A G E=$ age of farmers (in year); $E D U=$ formal education $(\mathrm{D}=1$ for senior high school \& the higher education, otherwise D =0); SIZE = land size (in log); SEED $=$ type of seed $(\mathrm{D}=1$ for high-yielding certified seed, otherwise $\mathrm{D}=0$ ); FIELD = irrigated rice field $(\mathrm{D}=1$ for cultivation in irrigated rice field, otherwise $\mathrm{D}=0) ; P E S T=$ pests and diseases $(\mathrm{D}=1$ if there were pests and diseases, otherwise $\mathrm{D}=0)$; $G O \mathrm{~V}$ $=$ government assistance $(\mathrm{D}=1$ for farmers who gets production input assistance free from government, otherwise $\mathrm{D}=0) ; \quad C R E D I T=$ farmers' access to credit $(\mathrm{D}=1$ if farmers don't experience difficulty to obtain credit from formal financial institutions, otherwise $\mathrm{D}=0), X_{11}=$ pests management $(\mathrm{D}=1$ if using pesticides, otherwise $\mathrm{D}=0$ ); $S U M, J A V A$, $K A L, S U L$ respectively is regional dummy variable for Sumatera, Java, Kalimantan and Sulawesi. Parameters are estimated by maximum likelihood method using Eviews software 7.1 version. Since the dataset does contain capital variable we assume capital separability in the interval of our analysis.

\section{Results and discussion}

\section{Descriptive statistics of variables}

Table 1 represents summary statistics of variables. The first five variables in Table 1 are the output and inputs used in the DEA models. Meanwhile, nine other variables are the specific factors in rice farming used in Tobit models to explain the variation in technical efficiency and technology gap between the farmers. 


\begin{tabular}{|c|c|c|c|c|c|c|}
\hline \multirow{3}{*}{ Variable } & \multicolumn{2}{|c|}{ Sumatera } & \multicolumn{2}{|c|}{ Java } & \multicolumn{2}{|c|}{ Bali \& Nusa Tenggara } \\
\hline & \multicolumn{2}{|c|}{$\mathrm{n}=1259$} & \multicolumn{2}{|c|}{$\mathrm{n}=3273$} & \multicolumn{2}{|c|}{$n=243$} \\
\hline & Mean & SD & Mean & SD & Mean & SD \\
\hline Rice (kg) & 2514 & 1949.42 & 1603 & 1144.29 & 2532 & 1871.84 \\
\hline Harvested area (square meters) & 4833 & 3664.65 & 2823 & 1938.45 & 4043 & 2827.20 \\
\hline Seed $(\mathrm{kg})$ & 27 & 25.22 & 13 & 9.36 & 24 & 19.36 \\
\hline Fertilizer $(\mathrm{kg})$ & 176 & 148.04 & 148 & 110.59 & 215 & 161.24 \\
\hline Labor (person days) & 48 & 39.94 & 44 & 27.67 & 56 & 37.68 \\
\hline Net income (000 rupiahs) & 3927 & 3519.42 & 2052 & 1701.66 & 3502 & 2859.38 \\
\hline Age of farmers (year) & 49 & 11 & 51 & 10 & 48 & 12 \\
\hline Education (dummy) & 0.37 & 0.48 & 0.31 & 0.46 & 0.33 & 0.47 \\
\hline Land size (square meters) & 5897 & 5037.17 & 3167 & 2178.68 & 4844 & 4080.76 \\
\hline Type of seed (dummy) & 0.50 & 0.50 & 0.56 & 0.50 & 0.48 & 0.50 \\
\hline Irrigated rice field (dummy) & 0.50 & 0.50 & 0.57 & 0.50 & 0.70 & 0.46 \\
\hline Pests \& dieses (dummy) & 0.57 & 0.50 & 0.50 & 0.50 & 0.39 & 0.49 \\
\hline Government assistance (dummy) & 0.38 & 0.49 & 0.33 & 0.47 & 0.45 & 0.50 \\
\hline Access to credit (dummy) & 0.56 & 0.50 & 0.54 & 0.50 & 0.53 & 0.50 \\
\hline
\end{tabular}

Source: Author's tabulation based on BPS data

Table 1: Summary statistics of variables used in DEA and Tobit models.

\begin{tabular}{|c|c|c|c|c|c|c|}
\hline \multirow{3}{*}{ Variable } & \multicolumn{2}{|c|}{ Kalimantan } & \multicolumn{2}{|c|}{ Sulawesi } & \multicolumn{2}{|c|}{ National (pooled data) } \\
\hline & \multicolumn{2}{|c|}{$\mathrm{n}=287$} & \multicolumn{2}{|c|}{$\mathrm{n}=475$} & \multicolumn{2}{|c|}{$\mathrm{N}=5537$} \\
\hline & Mean & SD & Mean & SD & Mean & SD \\
\hline Rice (kg) & 2112 & 1194.36 & 3084 & 2635.11 & 2004 & 1650.98 \\
\hline Harvested area (square meters) & 4582 & 2597.94 & 5589 & 4926.88 & 3662 & 3024.18 \\
\hline Seed (kg) & 22 & 13.53 & 29 & 28.5 & 19 & 18.36 \\
\hline Fertilizer $(\mathrm{kg})$ & 118 & 74.46 & 200 & 203.61 & 160 & 133.01 \\
\hline Labor (person days) & 68 & 50.42 & 50 & 26.74 & 47 & 33.21 \\
\hline Net income (000 rupiahs) & 3679 & 2286.43 & 3583 & 3469.27 & 2757 & 2629.88 \\
\hline Age of farmers (year) & 47 & 9 & 47 & 9 & 50 & 11 \\
\hline Education (dummy) & 0.33 & 0.47 & 0.37 & 0.48 & 0.33 & 0.47 \\
\hline Land size (square meters) & 6181 & 3949.75 & 8262 & 7051.99 & 4455 & 4149.88 \\
\hline Type of seed (dummy) & 0.41 & 0.49 & 0.55 & 0.50 & 0.54 & 0.50 \\
\hline Irrigated rice field (dummy) & 0.40 & 0.49 & 0.51 & 0.50 & 0.54 & 0.50 \\
\hline Pests \& dieses (dummy) & 0.39 & 0.49 & 0.59 & 0.49 & 0.51 & 0.50 \\
\hline Government assistance (dummy) & 0.40 & 0.49 & 0.28 & 0.45 & 0.35 & 0.48 \\
\hline Access to credit (dummy) & 0.31 & 0.46 & 0.47 & 0.50 & 0.53 & 0.50 \\
\hline
\end{tabular}

Source: Author's tabulation based on BPS data

Table 1: Summary statistics of variables used in DEA and Tobit models (continuation).

\section{Technical efficiency and technology gap}

Table 2 reports summary statistics of the regional technical efficiency (TE-K), meta technical efficiency (TE-MF) and metatechnology ratio (MTR) obtained from DEA estimation. The TE-K, TE-MF and MTR are varying between the regions. The average of TE-K is 0.767 in Java and 0.807 in Bali \& Nusa Tenggara, for example, indicate that the maximum output obtained using the production inputs with the existing technology in Java, and Bali is around $77 \%$ and $80 \%$ of the output potential in both regions respectively. Meanwhile, the average of MTR 0.838 in Java and 0.870 in Bali $\&$ Nusa Tenggara indicate that the maximum output which achieved in Java and Bali \& Nusa Tenggara using the production inputs in those regions respectively with metatechnology is approximately $87 \%$ and $72 \%$ of the maximum output represented by metafrontier.

In all regions, the TE-MF is slightly lower than 
the TE-K. For example, the average TE-MF 0.630 for Java is lower than the average TE-K 0.767 for this region. Based on TE-MF, it can be said that the technical efficiency in Bali and Nusa Tenggara region is the highest compared to any other region. In contrast, technical efficiency in Kalimantan is the lowest than in any other regions.
Based on the DEA estimation of regional frontiers, metafrontier and metatechnology ratio, TE-K, TE-MF and MTR for fifteen provinces covered by the five groups of region can also be obtained. Descriptive statistics of the TE-K, TE-MF and MTR by province are presented in Table 3 . In this context, the table 3 is basically describing

\begin{tabular}{lccccc}
\hline Region & Statistics & Mean & SD & Minimum & Maximum \\
\hline Sumatera & TE-K & 0.768 & 0.167 & 0.270 & 1.000 \\
$(\mathrm{n}=1259)$ & MTR & 0.818 & 0.102 & 0.489 & 1.000 \\
Java & TE-MF & 0.624 & 0.140 & 0.227 & 1.000 \\
$(\mathrm{n}=3273)$ & TE-K & 0.767 & 0.139 & 0.270 & 1.000 \\
& MTR & 0.838 & 0.132 & 0.579 & 1.000 \\
Bali \& Nusa & TE-MF & 0.630 & 0.096 & 0.225 & 1.000 \\
Tenggara & TE-K & 0.807 & 0.136 & 0.519 & 1.000 \\
$(\mathrm{n}=243)$ & MTR & 0.870 & 0.077 & 0.587 & 1.000 \\
& TE-MF & 0.698 & 0.118 & 0.489 & 1.000 \\
Kalimantan & TE-K & 0.787 & 0.138 & 0.445 & 1.000 \\
$(\mathrm{n}=287)$ & MTR & 0.717 & 0.138 & 0.457 & 1.000 \\
& TE-MF & 0.563 & 0.150 & 0.380 & 1.000 \\
Sulawesi & TE-K & 0.801 & 0.114 & 0.444 & 1.000 \\
$(\mathrm{n}=475)$ & MTR & 0.846 & 0.060 & 0.573 & 1.000 \\
& TE-MF & 0.678 & 0.115 & 0.402 & 1.000 \\
National & TE-K & 0.773 & 0.144 & 0.270 & 1.000 \\
(N=5537) & MTR & 0.829 & 0.123 & 0.457 & 1.000 \\
& TE-MF & 0.633 & 0.116 & 0.225 & 1.000 \\
\hline
\end{tabular}

Source: DEA estimation

Table 2: Summary statistics of the technical efficiencies and metatechnology ratios by region.

\begin{tabular}{|c|c|c|c|c|c|c|c|}
\hline \multirow{2}{*}{ Province } & \multirow{2}{*}{$\mathrm{n}$} & \multicolumn{2}{|l|}{ TE-K } & \multicolumn{2}{|l|}{ MTR } & \multicolumn{2}{|l|}{ TE-MF } \\
\hline & & Mean & SD & Mean & SD & Mean & SD \\
\hline Nanggroe Aceh Darussalam & 155 & 0.739 & 0.184 & 0.813 & 0.084 & 0.598 & 0.152 \\
\hline North Sumatera & 390 & 0.772 & 0.129 & 0.870 & 0.067 & 0.667 & 0.103 \\
\hline West Sumatera & 212 & 0.648 & 0.198 & 0.749 & 0.110 & 0.479 & 0.152 \\
\hline South Sumatera & 261 & 0.836 & 0.144 & 0.776 & 0.123 & 0.636 & 0.096 \\
\hline Lampung & 241 & 0.813 & 0.141 & 0.844 & 0.067 & 0.684 & 0.121 \\
\hline West Java & 1116 & 0.707 & 0.119 & 0.861 & 0.059 & 0.606 & 0.095 \\
\hline Central Java & 958 & 0.907 & 0.061 & 0.662 & 0.044 & 0.600 & 0.063 \\
\hline East Java & 990 & 0.695 & 0.116 & 0.971 & 0.042 & 0.673 & 0.102 \\
\hline Banten & 209 & 0.784 & 0.113 & 0.892 & 0.068 & 0.696 & 0.092 \\
\hline Bali & 89 & 0.862 & 0.091 & 0.839 & 0.064 & 0.722 & 0.085 \\
\hline West Nusa Tenggara & 154 & 0.775 & 0.147 & 0.889 & 0.079 & 0.685 & 0.132 \\
\hline West Kalimantan & 110 & 0.764 & 0.170 & 0.871 & 0.082 & 0.666 & 0.168 \\
\hline South Kalimantan & 177 & 0.801 & 0.111 & 0.621 & 0.053 & 0.498 & 0.091 \\
\hline Central Sulawesi & 84 & 0.803 & 0.161 & 0.829 & 0.081 & 0.666 & 0.151 \\
\hline South Sulawesi & 391 & 0.800 & 0.101 & 0.681 & 0.105 & 0.850 & 0.054 \\
\hline
\end{tabular}

Source: DEA estimation

Table 3: Summary statistics of the technical efficiencies andmetatechnology ratios by province. 
the distribution of the TE-K, TE-MF and MTR regions to the province. Therefore, the interpretation of the score TE-K, TE-MF and MTR is not different from the previous paragraph.

3. The determinants of technical efficiency and technology gap

The maximum likelihood estimation results of such determining factors to the TE-K, TE-MF and MTR are shown in Table 4.

\begin{tabular}{|c|c|c|c|c|}
\hline Variable & Symbol & TE-K & TE-MF & MTR \\
\hline \multirow[t]{2}{*}{ Constant } & & $0.6660 * * *$ & $0.3730 * * *$ & $0.6436 * * *$ \\
\hline & & $(0.0233)$ & $(0.0185)$ & $(0.0208)$ \\
\hline \multirow[t]{2}{*}{ Net income } & INCOME & $0.0313 * * *$ & $0.0680 * * *$ & $0.0515^{* * *}$ \\
\hline & & $(0.0034)$ & $(0.0027)$ & $(0.003)$ \\
\hline \multirow[t]{2}{*}{ Age } & AGE & $0.0009 * * *$ & $-0.0001 * * *$ & $-0.0008 * * *$ \\
\hline & & $(0.0002)$ & $(0.0001)$ & $(0.0002)$ \\
\hline \multirow[t]{2}{*}{ Education } & EDU & $0.0542 * * *$ & $0.0411 * * *$ & $0.0094 * * *$ \\
\hline & & $(0.0038)$ & $(0.0028)$ & $(0.0036)$ \\
\hline \multirow[t]{2}{*}{ Land size } & SIZE & $-0.0253^{* * *}$ & $-0.0322 * * *$ & $-0.0169 * * *$ \\
\hline & & $(0.0035)$ & $(0.0029)$ & $(0.0032)$ \\
\hline \multirow[t]{2}{*}{$\begin{array}{l}\text { Type } \\
\text { of seed }\end{array}$} & SEED & $0.0799 * * *$ & $0.0316^{* * *}$ & $-0.0411 * * *$ \\
\hline & & $(0.0036)$ & $(0.0024)$ & $(0.0034)$ \\
\hline \multirow[t]{2}{*}{$\begin{array}{l}\text { Irrigated } \\
\text { rice field }\end{array}$} & FIELD & $0.0480^{* * *}$ & $0.0498^{* * *}$ & $0.0122 * * *$ \\
\hline & & $(0.0034)$ & $(0.0024)$ & $(0.0033)$ \\
\hline \multirow[t]{2}{*}{$\begin{array}{l}\text { Pests \& } \\
\text { diseases }\end{array}$} & PEST & $-0.0631 * * *$ & $-0.0325^{* * *}$ & $0.0169 * * *$ \\
\hline & & $(0.0035)$ & $(0.0025)$ & $(0.0034)$ \\
\hline \multirow[t]{2}{*}{$\begin{array}{l}\text { Government } \\
\text { assistance }\end{array}$} & GOV & $0.0607 * * *$ & $0.0335^{* * *}$ & $-0.0135^{* * *}$ \\
\hline & & $(0.0038)$ & $(0.0027)$ & $(0.0035)$ \\
\hline \multirow[t]{2}{*}{$\begin{array}{l}\text { Access } \\
\text { to credit }\end{array}$} & CREDIT & $-0.0391 * * *$ & $-0.0146^{* * *}$ & $0.0167^{* * *}$ \\
\hline & & $(0.0034)$ & $(0.0024)$ & $(0.0033)$ \\
\hline \multirow[t]{2}{*}{ Sumatera } & SUM & $-0.0192 * * *$ & $-0.0570 * * *$ & $-0.0537 * * *$ \\
\hline & & $(0.0071)$ & $(0.0062)$ & $(0.0056)$ \\
\hline \multirow[t]{2}{*}{ Java } & JAVA & $-0.0297 * * *$ & $-0.0328 * * *$ & -0.0071 \\
\hline & & $(0.0067)$ & $(0.0057)$ & $(0.0055)$ \\
\hline \multirow[t]{2}{*}{ Kalimantan } & KAL & -0.0025 & $-0.1176 * * *$ & $-0.1505 * * *$ \\
\hline & & $(0.0082)$ & $(0.0086)$ & $(0.0092)$ \\
\hline \multirow[t]{2}{*}{ Sulawesi } & SUL & $0.0268 * * *$ & $0.0128 *$ & $-0.0158 * * *$ \\
\hline & & $(0.0077)$ & $(0.0068)$ & $(0.0061)$ \\
\hline \multicolumn{2}{|l|}{$\begin{array}{l}\text { Likelihood } \\
\text { ratio }\end{array}$} & $2937.421 * * *$ & $3170.937^{* * *}$ & $913.6276^{* * *}$ \\
\hline \multicolumn{5}{|c|}{$\begin{array}{l}\text { Notes: the number in the } \\
* * \text {, and } * \text { indicates statisti } \\
\text { level of significance, resp } \\
\text { Source: own calculation }\end{array}$} \\
\hline
\end{tabular}

Net income from rice farming has a positive and significant effect to the TE-K, TE-MF and MTR mean that the TE-K, TE-MF and MTR will increase as the net income increase. The age of farmers has a positive and significant effect on the TE-K which support the previous studies [such as Llewelyn and Williams (1996); Fabiosa et al. (2004); Kusnadi et al. (2011); Suharyanto et al. (2013)]. This suggests that old farmers are more efficient than young farmers because their experiences in rice cultivation are more than young farmers. In contrast, effect of age to the TE-MF and MTR is negative. This situation may occur because of the old farmers are usually reluctant to adopt and use the new technologies or more efficient production methods.

All the coefficients of formal education are positive and significant, indicating that the average TE-K, TE-MF and MTR of the farmers who had senior high school education and higher education is greater than farmers who had junior school education and lower education. The positive and significant effect of formal education on technical efficiency also support previous studies [such as Widodo (1986); Fabiosa et al. (2004)]. Land size has a negative and significant effect on the TE-K, TE-MF and MTR indicate that small farmers are more efficient than the large farmer. Based on literature this case is common in developing countries.

Coefficients of seed types are positive and significant to the TE-K and TE-MF, meaning that the average of TE-K and TE-MF obtained from the use of certified high-yielding seed is greater compared to non certified high-yielding seed. In fact, there are many farmers in Indonesia who do not use certified high-yielding seed due to constraints such as purchasing power, price, and location. This may cause a negative effect of the certified high-yielding seed to the MTR as shown in Table 4. Irrigated rice field dummy variable has a positive and significant effect on the TE-K, TE-MF and MTR. These indicate that the average TE-K, TE-MF and MTR of rice cultivation in irrigated rice field is greater compared to non irrigated rice field. The presence of pest and diseases reduced the technical efficiency of rice farming. However, a decrease in the average TE-K caused by pests and diseases is greater than a decrease in the average TE-MF, and therefore the effect on the MTR is positive.

Government assistance in the form of inputs which are provided free to the farmers has a positive and significant effect to the technical efficiency of rice arming. However, its effect to MTR is negative and significant, meaning that the technology 
gap tends to widened due to not all farmers could access such assistance. Access to credit has a negative and significant effect to the technical efficiency, but its effect to the MTR is positive and significant. However, not all the farmers in Indonesia could access credit because of several reasons, for example, farmers may not have collateral, credit application procedures maybe complicated, farmers do not have any information about credit procedures, the distance between the location of farmers and the credit institutions might be quite far (BPS, 2008). Most of these farmers rely on self-financing in operating of rice farming. This situation may cause a negative effect of access to credit on technical efficiency.

Finally, the positive coefficient of Sulawesi for TE-K and TE-MF indicates that rice farming in this region is more efficient to the other regions including Bali \& Nusa Tenggara. Furthermore, the negative coefficient of the regional dummy variables showed that the average MTR for the regions is slightly less than the average MTR for Bali \& Nusa Tenggara. In other word, this indicates that technology gap of rice farming in Sumatera, Java, Kalimantan and Sulawesi is wider than in Bali and Nusa Tenggara.

\section{Conclusions}

The technical efficiency based on metafrontier analysis (TE-MF) can be decomposed into regional technical efficiency (TE-K), and metatechnology ratio (MTR) which measure technology gap. The average TE-MF of rice farming in Indonesia is slightly lower than TE-K, so that the average of MTR is quite high. This indicates that technology gap between the technology adopted by the farmers and the best available technology is quite small. A number of factors have a positive and significant effect on the technical efficiency and technology gap, namely net income from rice farming, education, and irrigated rice field. Land size showed a negative effect on technical efficiency and technology gap. Meanwhile, the effect of other factors such as age of farmers and access to credit on the technical efficiency as well as the effect of seed type and government assistance on technology gap is ambiguous.

In term of policy, an increase in the technical efficiency as well as reduction in the technology gap (or increase in the MTR) is necessary. Therefore, net income, education and irrigated fields should be considered in the policy to increase technical efficiency and reducing the technology gap. Net income obtained by farmers from rice farming should rise not only to improve their standard of living worthily, but also improved their capability to reinvest part of the net income on productive assets for increased rice production. However, the net income can be influenced by a number of factors which are not addressed in this study.

Formal education either general education and vocational education for the farmers should be increased at least up to the senior high school through the 12-years compulsory education program to improve farmers' knowledge on information and technology relating to agricultural practice, make farmers becomes more creative, and innovative. In addition, non-formal education for the farmers is also important to encourage the use a better agricultural practice. Hence, the existence of field school in integrated crop management should be maintained and developed to improve the knowledge and skills of the farmers through direct practice.

Furthermore, the existing irrigated rice field ought to be maintained. Accordingly, the government must be able to prevent the conversion of agricultural land for non-agricultural activities through enforcement of the related laws and regulations. The existing irrigation infrastructures which still function properly must be maintained, while the damaged irrigation infrastructure should be repaired and constructed. These are very importance to guarantee the adequate water supply for rice cultivation in normal weather condition, and especially in extreme weather conditions. The construction of irrigation infrastructure is also needed to support the new rice field expansion in areas that have been designated as agricultural areas for food commodity outside Java.

Corresponding author:

Tri Haryanto

Department of Economics, Airlangga University, Kampus B-Jalan Airlangga 4, Surabaya 60286, Indonesia Phone:+62-813-3040-6631.Fax:+62-31-5026288,E-mail:tri.h@feb.unairac.id; soemantri2@yahoo.com 


\section{References}

[1] Aigner, D. J., and Chu, S. F. (1968) „On estimating the industry production function“, The American Economic Review, Vol. 58, No. 4, pp. 826-829. ISSN 00028282.

[2] Alston, J. M., Chan-Kang, C., Marra, M.C., Pardey, P. G. and Wyatt, T. J. (2000) „Research return redux: a meta-analysis of the return to agricultural R\&D“, The Australian Journal of Agricultural and Resource Economics, Vol. 44, No. 2, pp. 185-215. ISSN 1364985X. DOI 10.1111/1467-8489.00107.

[3] Battese, G. E., Rao, D. S. P., O’Donnell, C. J. (2004) „A metafrontier production function for estimation of technical efficiencies and technology gaps for firms operating under different technologies“, Journal of Productivity Analysis, Vol. 21, pp. 91-103. ISSN 0895562X. DOI 10.1023/B:PROD.0000012454.06094.29.

[4] Battese, G. E . and Rao, D. S. P. (2002) „Technology gap, efficiency, and a stochastic metafrontier function“, International Journal of Business and Economics, Vol. 1, No. 2, pp. 87-93. ISSN 1544-8037.

[5] Brázdik, F. (2006) „Non-parametric analysis of technical efficiency: Factors affecting efficiency of West Java rice farms“. Working paper series. Center for Economic Research and Graduate Education Academy of Sciences of the Czech Republic Economics Institute, Vol. 286, pp.1-45. ISSN 1211-3298.

[6] Cechura, L., Hockmann, H., Malý, M. and Žáková Kroupová, Z. (2015) „Comparison of technology and technical efficiency in cereal production among EU countries“, Agris on-line Papers in Economics and Informatics, Vol. VII, No. 2, pp. 27-37. ISSN 18041930.

[7] Chavas, J. P. and Aliber, M. (1993) „An analysis of economic efficiency in agriculture: A nonparametric approach“, Journal of Agricultural and Resource Economics, Vol.18, No. 1, pp. 1-16. ISSN 10685502.

[8] Chavas, J. P., Petrie, R. and Roth, M. (2005) „Farm household production efficiency: Evidence from the Gambia“, American Journal of Agricultural Economics, Vol. 87, No. 1, pp. 160-179. ISSN 00029092.

[9] Chen, Z. and Song, S. (2008) „Efficiency and technology gap in China's agriculture: A regional meta-frontier analysis“, China Economic Review, Vol. 19, pp. 287-296. ISSN 1043951X. DOI 10.1016/j.chieco.2007.03.001.

[10] Fabiosa, J. F, Jensen, H. H. and Yan. D. (2004) „Do macroeconomic shocks impact the economic efficiency of small farmers? The case of wetland rice farmers in Indonesia“, Working Paper 04-WP 364, Center for Agricultural and Rural Development Iowa State University, May 2004. [Online]. Available: www.card.iastate.edu [Accessed: 25 May 2011].

[11] Fulginiti, L. E. and Perrin, R. K. (1998) „Agricultural productivity in developing countries“, Agricultural Economics, Vol. 19, pp. 45-51, ISSN 01695150.

[12] Gunaratne, L. H. P. and Leung, P. S. (2000) „Asian black tiger shrimp industry: a meta-production frontier analysis“, In:. Leung, PingSun and Khem R. Sharma (eds): A Collections of Research Paper Based on the ADB/NACA Farm Performance Survey, Bangkok: Network of Aquaculture Centers in Asia Pacific, pp. 55-68. ISBN 000000000.

[13] Hayami, Y. (1969) „Sources of agricultural productivity gap among selected countries“, American Journal of Agricultural Economics, Vol. 51, No. 3, pp. 564-575. ISSN 00029092.

[14] Hayami, Y. (1970) „On the use of the Cobb-Douglas production function on the cross-country analysis of agricultural production“, American Journal of Agricultural Economics, Vol. 52, No. 2, pp. 327-329. ISSN 00029092.

[15] Hayami, Y. (1969) „Sources of agricultural productivity differences among countries resource accumulation, technical inputs and human capital“, Staff Paper Series P69-24 University of Minnesota Institute of Agriculture, November 1969. [Online]. Available: http://ageconsearch. umn.edu/bitstream/14272/1/p69-24.pdf [Accessed: 7 September 2012]. DOI 10.2307/1237909 
[16] Hayami, Y. and Ruttan, V. W. (1970) „Agricultural productivity differences among countries“, The American Economic Review, Vol. 60, No. 5, pp. 895-911. ISSN 00028282.

[17] Hayami, Y. and Ruttan, V. W. (1972), Agricultural productivity differences“, Journal of Northeastern Agricultural Economics Council, Vol.1, No. 1, pp. 1-13.

[18] Hayami, Y. and Ruttan, V. W. (1985) „Agricultural development: An international perspective revised and expanded edition“", Johns Hopkins University Press. ISBN 978-0801823763.

[19] Kawagoe, T., Hayami, Y. and Ruttan, V. W. (1985) „The intercountry agricultural production function and productivity differences among countries", Journal of Development Economics, Vol. 19, pp. 113-132, ISSN 0304-3878. DOI 10.1016/0304-3878(85)90041-0.

[20] Kawagoe, T. and Hayami, Y. (1983) „The production structure of world agriculture: An intercountry cross-section analysis“, The Developing Economies, Vol. 21, pp. 189-206. ISSN 1746-1049. DOI 10.1111/j.1746-1049.1983.tb01082.x.

[21] Kramol, P., Villano, R., Kristiansen, P. and Fleming, E. (2015) „Productivity differences between organic and other vegetable farming systems in Northern Thailand“, Renewable Agriculture and Food Systems, Vol. 30, No. 02, pp. 154-169. ISSN 17421705. DOI http://dx.doi.org/10.1017/S1742170513000288.

[22] Kudaligama, V. P. and Yanagida, Y. F. (2000) ,A comparison of intercountry agricultural production functions: A frontier function approach“, „Journal of Economic Development“, Vol. 25, No. 1, pp. 57-74. ISSN 0254-8372.

[23] Kusnadi, N., Tinaprilla, N., Susilowati, S. H. and Purwoto, A. (2011) „Rice farming efficiency analysis in some rice producing areas in Indonesia“, Jurnal Agro Ekonomi, Vol. 29, No. 1, pp. 25- 48. ISSN 0216-9053.

[24] Latruffe, L., Fogarasi, J. and Desjeux, Y. (2012) „Efficiency, productivity and technology comparison for farms in Central and Western Europe: The case of field crop and dairy farming in Hungary and France“, Economic Systems, Vol. 36. No. 2, pp. 264-278. ISSN 0939-3625. DOI 10.1016/j.ecosys.2011.07.002.

[25] Lau, L. J. and Yotopoulos, P. A. (1971) „A test of relative efficiency and application to Indian Agriculture“, The American Economic Review, Vol. 61, No. 1, pp. 94-109. ISSN 00028282.

[26] Lau, L. J. and Yotopoulos, P. A. (1989) „The meta-production function approach to technical change in world agriculture“, Journal of Development Economics, Vol. 31, pp. 241-269. ISSN 0304-3878.

[27] Llewelyn, R. V. and Williams, J. R. (1996) „Nonparametric analysis of technical, pure technical, and scale efficiencies for food crop production in East Java, Indonesia“, Agricultural Economics, Vol. 15, pp. 113-126. ISSN 01695150. DOI 10.1016/S0169-5150(96)01202-9.

[28] Makki, M. F. and Suslinawati, Y. F. R. (2012) „Impacts of climate change on productivity and efficiency paddy farms: Empirical evidence on tidal swamp land South Kalimantan Province - Indonesia“" Journal of Economics and Sustainable Development, Vol. 3, No. 14, pp. 66-72. ISSN 2222-1700.

[29] Marra, M. C. and Schurle, B.W. (1994) „Kansas wheat yield risk measures and aggregation: A metaanalysis approach“, Journal of Agricultural and Resource Economics, Vol. 19, No. 1, pp. 69-77. ISSN 10685502.

[30] Moreira, V. H. and Bravo-Ureta, B. E. (2010) „Technical efficiency and metatechnology ratios for dairy farms in three southern cone countries: a stochastic meta-frontier model“, Journal of Productivity Analysis, Vol. 33, pp. 33-45. ISSN 0895562X. DOI 10.1007/s11123-009-0144-8.

[31] Mulwa, R., Emrouznejad, A., and Muhammad, L. (2009) „Economic efficiency of smallholder maize producers in Western Kenya: A DEA meta-frontier analysis“, International Journal of Operational Research, Vol. 4, No. 3, pp. 250-267. ISSN 17457645. DOI http://dx.doi.org/10.1504/IJOR.2009.023284. 
[32] Nguyen, K. T. and Fisher, T. C. G. (2014) „Efficiency analysis and the effect of pollution on shrimp farms in the Mekong river delta“, Aquaculture Economics \& Management, Vol. 8, No. 4, pp. 325-343. ISSN 13657305. DOI 10.1080/13657305.2014.959209.

[33] Nkamleu, G. B., Nyemeck, J. and Sanogo, D. (2009) „Metafrontier analysis of technology gap and productivity difference in African agriculture“, MPRA Paper No. 15103, May 2009. [Online]. Available: http://mpra.ub.uni-muenchen.de/15103 [Accessed: 13 November 2013]

[34] O'Donnell, C. J., Rao, D. S. P. and Battese, G. E. (2008) „Metafrontier frameworks for the study of firm-level efficiencies and technology ratios“, Empirical Economics, Vol. 34, pp. 231-255. ISSN 03777332. DOI 10.1007/s00181-007-0119-4.

[35] Rao, D. S. P., O’Donnel, C. J. and Battese, G. E. (2003) „Metafrontier functions for the Study of interregional productivity differences", Working Paper Series No. 01/2003. Centre for Efficiency and Productivity Analysis, School of Economics University of Queensland, September 2003. [Online]. Available: http://www.uq.edu.au/economics/cepa/docs/WP/WP012003.pdf [Accessed: 13 November 2013].

[36] Squires, D. and Tabor, S. (1991) „Technical efficiency and future production gains in Indonesian agriculture", The Developing Economies, Vol. XXIX-3, pp. 258-270. ISSN 1746-1049. DOI 10.1111/j.1746-1049.1991.tb00211.x.

[37] Suharyanto Mulyo, J. H., Darwanto, D. H. and Widodo, S. (2013) „Technical efficiency analysis of integrated crop management (ICM) of rice in Bali, Indonesia“, SEPA, Vol. 9, No. 2, pp. 219-230. ISSN 1829-9946.

[38] Tung, D. T. (2014) „Regional differences in measuring the technical efficiency of rice production in Vietnam: A metafrontier approach“, Journal of Agricultural Science“, Vol. 6, No. 10, pp. 147157. ISSN 1916-9752. DOI 10.5539/jas.v6n10p147.

[39] Uddin, M. M., Brümmer, B. and Peters, K. J. (2014) „Technical efficiency and metatechnology ratios under varying resource endowment in different production systems: A stochastic metafrontier model in Bangladesh dairy farms", China Agricultural Economics Review, Vol. 6, No. 3, pp. 485-505. ISSN 1756-137X. DOI 10.1108/CAER-06-2013-0088.

[40] Widodo, R. (1986) ,An econometrics study of production efficiency among rice farmers in irrigated lowland villages in Java, Indonesia“, Ilmu Pertanian, Vol. 4, No. 3, p. 121-145. 